\title{
The Course of Pre-Service Teachers' Expectations in School Practices and the Factors Affecting Their Expectations
}

\author{
Ramazan Săg \\ Division of Curriculum \& Instruction, Department of Educational Science, Education Faculty, Mehmet Akif Ersoy \\ University, Burdur, Turkey \\ Email: rsag@mehmetakif.edu.tr
}

Received 4 March 2014; revised 4 April 2014; accepted 11 April 2014

Copyright (C) 2014 by author and Scientific Research Publishing Inc. This work is licensed under the Creative Commons Attribution International License (CC BY). http://creativecommons.org/licenses/by/4.0/

\section{(c) (i) Open Access}

\begin{abstract}
It is known that expectations of pre-service teachers will change during the process of the school practice especially depending on the interactions they establish with practice teachers and supervisors. The study was conducted at a faculty of education in a big city with pre-service teachers in senior science class using split-plot design. Data were obtained through three measurement levels including initial, intermediate, and final stages in the study which was carried out with 44 preservice teachers 27 of whom were female. Qualitative data were obtained through focus group interviews made with 6 pre-service teachers, 3 of whom were females following measurement levels. Descriptive statistics were used for analyzing the quantitative data while the ANOVA statistic of Friedman which is a nonparametric test was used for analyzing the point differences. Descriptive analysis was used for analyzing the qualitative data and the data were interpreted together with the findings obtained from the quantitative data. It was detected that the initial expectations of the pre-service teachers were higher in the collegiality and leadership categories compared to guidance but their expectations tended to drop dramatically over time. Among the factors that are considered to be the potential factors of the decrease, whether the practice school, which is a new structure, was introduced to the pre-service teachers at the beginning of the academic year and whether they were welcomed in a positive or negative manner at the practice school constituted the most critical turning points.
\end{abstract}

\section{Keywords}

Teacher Education; School Practices; Expectations; Formative Evaluation 


\section{Introduction}

School practices of pre-service teachers are considered to be the most important element of pre-service teacher training as they enable pre-service teachers to learn professional skills pre-first hand as well as giving them the opportunity to have their first professional experience for adapting to practice schools which are new to them (Calderhead, 1999; Darling-Hummond, 2003; Selçuk, 2001; Zeichner, 2002). Practice teachers and instructors are assigned for providing professional guidance with the aim of helping pre-service teachers to adapt to a new socio-cultural structure during this process as well as improving their professional skills. There is no doubt that successful professional training of pre-service teachers depends on arrangement and quality of training experience that provides opportunities for learning and improving the skills required by the profession. (Ball \& Cohen, 1999; Beck \& Kosnik, 2002; Feiman-Nemser \& Buchman, 2013). It is observed that the quality of the said training experience is closely related to a few conditions. These can be listed as the suitability of practice schools, (Beck \& Kosnik, 2002; Zeichner, 2002), and the inconsistency between the curriculums of the practice schools and faculties (Zeichner, 2002) the variety and quality of the personal traits of practice teachers and supervisors (Sosik \& Godshalk, 2000) and the practices towards which pre-service teachers are directed in accordance with their competence related to their missions (Kiraz, 2003; Sağ, 2007; Paker, 2000), and the quality of the professional guidance provided for pre-service teachers during this process (Ball \& Cohen, 1999; Grossman, 2011; Paker, 2011).

It is considered that it is important to meet the expectations of pre-service teachers in order to carry out school practices efficiently. Stevenson, MacKeogh, and Sander (2006) argue that students can be motivated in advance and instructors can be prevented from making mistakes by predetermining the expectations of university students regarding the arrangement of the courses to be carried out and the way instructors are supposed to behave in the activities. The reason for this is that pre-service training has dimensions such as anxiety, stress, satisfaction and empathy not only for pre-service teachers (Mapfumo, Chitsiko, \& Chireshe, 2012; Sumsion, 1998) but also for training teachers (Hastings, 2004). The study, which results from this requirement, defines tips about the course of pre-service science teachers' expectations from two personnel directly responsible in school practices during the academic year and the potential factors affecting their expectations.

\subsection{The Expectation Concept and Its Use for Determining the Quality of Services at Universities}

The expectation concept, which is defined as "the opinion of an individual about certain conditions and circumstances or what is expected from him/her” in mental terms dictionary (Turkish Language Association (Türk Dil Kurumu, 2010), expectation heading), is known to be one of the important determiners of behavior formation (Bandura, 1971; Rotter, 1966). Cognitive theoreticians consider expectation one of the processes affecting perception which is defined as the process in which knowledge is the explanation and interpretation of information (Senemoğlu, 2009). Furthermore, Eysenck and Keane (2003) state that psychologists argue that the expectation concept functions as one of pre-behavior determiners in understanding of information processing by humans based on the top-down approach. As a matter of fact, Brophy (1982) states that the expectation concept is one of the basic determiners of individuals' perception of success within the framework of the "self-fulfilling prophecy" theory. Also, Vroom argues in his expectancy theory that the expectation concept has various functions such as "motivation" for acquiring the desired reward at the end of a process, a "criterion" for assessing the resulting product, and "valence based on a cognitive process" in the structure formed by people between the appropriate behavior and the resulting benefit (1964).

It is observed that the area of use of the expectation concept, which has been theorized to function as the initiator prompting the focus process of an individual at the beginning of learning (Rotter, 1966; Senemoğlu, 2009), motivation for maintaining the learning process (instrumentality), and criterion for evaluation of the learning quality by the learner (normativity/valence) (Gerring \& Zimbardo, 2012; Wroom, 1964), is expanding depending on the spreading of the social participation mentality. Higher education is one of these areas. Gallagher (2002) argues that the responsibility areas of universities are shifting from the state to the people for whom they provide services and the representatives of the sector they form economic alliance, conduct research with and raise graduates for Hill (1995) attributes another reason for shifting to the fact that students are the main consumers of the services depending on the developments at universities. Coaldrake (2002) argues that, due to the said shifting, the profiles of universities and the roles undertaken by them have become diversified 
and their significance has increased in the public opinion as higher education has become widespread.

Hill (1995) states that the studies related to determining the expectations of university students about general education services or those included in the curriculum and detecting the level at which their expectations have been met are used as a means of improving quality. That's because White (1999) states that the expectation concept is capable of showing sensitivity to time, experience, and encountered practices. Shank, Walker and Hayes (1995) argue that it is inevitable that "the quality of educational services" at universities will be insufficient against the constantly changing world due to various reasons because Hill (1995) and Parasuraman, Zeithaml, and Berry (1985) maintain that the services of universities, which constitute a service sector, have a variable nature as their qualities are abstract, unstable, holistic, and diversified. Sander, Stevenson, King and Coates (2000) state that the quality of the services produced by universities can be controlled via student expectations that are sensitive to time, experience, and encountered practices thanks to their abovementioned features. In this respect, Sander et al. (2000) state that the finding "expectations can be used for measuring the developments in student outputs" is crucial.

\subsection{The Place of the Expectation Concept in Curriculum Development}

Student expectations, emotions, and reactions constitute the individual-oriented data for assessing curricula. Physical, cognitive, affective, and social features, socio-economic natures, value systems, educational levels, particular interests and skills, communication skills, and expectations of students, who are one of the target sources in curriculum development, are defined as “individual needs” (Doğan, 1997; Oliva, 2009; Sönmez, 1990). In parallel with the abovementioned developments, as a part of curriculum, it is observed that the expectation concept started to be used as a means of data for arrangement, formatting, and evaluation of tutorial programme in 1990s (Stevenson, Sander, \& Naylor, 1997; Sander et al., 2000; Sander, 2006). As a matter of fact, some field experts (Demirel, 1999; Ertürk, 1971; Varış, 1988) draw attention to the fact that subject areas of curricula can be designed in a way that they can meet the expectations of individuals as well as the physiological, social, and ethical values of the society and individuals. Furthermore, Oliva (2009) suggests that "affection, acceptance, approval, belonging, success, and security feelings emerge as socio-psychological needs experienced by individuals based on social relations” (p. 189), therefore, those working on curricula must keep in mind that “educational needs do not exist beyond students (and the society) (2009: p. 189). Also Doğan (1997) states that knowing the opinions of students about themselves, their values, and future "expectations" will enable curriculum development experts to orientate their curricula in a way that they meet the "needs of students" (p. 128).

Another area of use of the expectation concept in relation to curricula is maintenance of especially educational services in a qualified manner and improvement and evaluation of the curricula that are executed. It is observed that two approaches have been developed in this context. One of them is related to sources taken as basis for defining expectations. The other one is related to the use of expectations. The defining approach includes studies based on the idea about how the elements of curricula such as activities, the attitudes and behaviors of instructors, particularly the targets must be. There are two sub approaches called "inside out” and "outside in". The "inside out" approach is based on the definition of expectations by instructors who know what is expected by students as well as what will be taught through learning and teaching services making students do this work. The "outside in" approach is, on the other hand, based on definition of expectations by people who will consume this service (Ling, 2010; Sander et al., 2000).

The second approach is related to using expectations for development and evaluation of curricula. In this context, it is observed that two models called ELPO and RASE have been developed. The ELPO model (Expectation Led Planned Organization) contains three stages. The model is based on the idea that curriculum must be used as a diagnostic feature before the execution of the curriculum, as a formative feature during the execution of the curriculum, and as the main determining feature while assessing the learning output in addition to students expectations and all elements of curriculum that are defined as the curriculum development process (for detail, see: Stevenson et al., 2006). The other one is the RASE (Responding Always to Students Expectations) model. The model contains six consecutive stages. These are: first compiling students expectations from the teacher and the teaching method, arranging the curriculum in accordance with the educational needs stated by students, preparing a detailed curriculum so that students can decide whether the curriculum is useful for them, telling the instructors about the desires of students, making sure that they are not carrying out practices that are considered bad practices by students, and conducting studies that will meet students' expectations for other assignments for which they wish to be prepared (for detail, see Stevenson et al., 1997). 


\subsection{Use of Expectations in Pre-Service Teacher Training and School Practices}

Without a doubt, the Council of Higher Education (Yüksek Öğretim Kurulu, 1998) is one of the institutions that have introduced the expectation concept to teacher training curricula at institutional level. The council has defined what must be done by pre-service teachers so that school practices can be fulfilled at the desired level and the missions of the personnel that will be employed during this process as "expectations" like many foreign universities and central institutions (Yüksek Öğretim Kurulu, 1998). It is observed that the council has defined the said expectations for all pre-service teacher training curricula in general terms without any exceptions. Accordingly, it expects all pre-service teachers to "prepare lessons”, “plan”, “enable the group and students with different learning traits to participate in learning and teaching activities with increased sensitivity", "to carry out studies aimed at assessing students success and evaluate practices” and "to behave like a teacher in physical, mental, and cognitive aspects” (Yüksek Öğretim Kurulu, 1998). The council has defined its expectations from practice teachers and supervisors as "providing a school environment where they will find the opportunity to undertake all responsibilities of the teaching profession”, “preparing a studying schedule”, “providing the opportunity to carry out observation and practices in different classroom environments", "providing support and guidance”, "providing the opportunity for discussing the observation report once a week”, "regular observation and evaluation by the responsible personnel”, "giving feedback on evaluation”, "providing the opportunity to speak with the practice teacher and the supervisor regarding evaluation" and "giving information beforehand about the works that will be carried out” (Yüksek Öğretim Kurulu, 1998).

It is observed that the abovementioned expectations of the council are defined as cornerstones for successful execution of the curricula of the lessons that are in fact within the scope of school practices. However, when the expectations are examined more closely, it is observed that their definitions are focused on improvement of the mechanical aspect of the teaching practice of pre-service teachers. But it is known that not only experts in the field of teacher training (Ball \& Cohen, 1999; Grossman \& McDonald, 2008) but also psychologists dealing with education, especially with learning (Goleman, 2007; Ilyenkov, 1974) and curriculum development experts (Doğan, 1997; Oliva, 2009; Tanner \& Tanner, 2007) state that not only the cognitive structure but also the affective and social qualities of training must not be overlooked.

When considered from this point of view, it is seen that the dimensions of the expectation concept concerning pre-service teachers are missing. It is known that the coherence between the expectation of practice teachers or supervisors and the expectations of pre-service teachers has a significant role. They are lack of communication based on collegiality and lack of critical feedback for vocational guidance which lie behind this expectation mismatch (Cole \& Knowles, 1993; Zeichner, 2010). For instance, Cole, and Knowles (1993) and Trevethan (2013) state that the expectations of pre-service teachers about school practice and teaching are different from the expectations and belief of practice teachers about pre-service teachers and their learning teaching. As a matter of fact, as it can be seen in studies directly focusing on the expectations of pre-service teachers (Să̆ , 2008) and in studies dealing with the roles perceived by them about those that are indirectly involved in this process (Aytaç, 2010; Demirkol, 2004; Kiraz, 2003; Paker, 2000; Sağ, 2008), it is observed that pre-service teachers state their emotional expectations about “collegiality” before learning the mechanical aspects of the teaching profession during school practices. Moreover, in some studies (Bektaş \& Ayvaz, 2012; Çelikkaya, 2011; Sağ, 2008) it is aimed to determine what kinds of expectations the pre-service teachers have at the beginning of the practice. As Atputhasamy's (2005) study focusing on realization level of the expectations that practice teachers have emphasizes, these expectations focus more on vocational guidance and leadership elements in which technical dimensions of teaching are considered.

In addition to studies aimed at defining the expectations of pre-service teachers in school practices, it is necessary to conduct research aimed at analyzing the changes between "the level of maintaining expectations in the middle of the term" and "the expectations realized by the end of the term" during the process and the circumstances related to responsible personnel causing the changes. That is because all professional or personal relations of responsible personnel with pre-service teachers bear the traces of their demographic, personal, professional competence as well as their competence related to pre-service teacher training (Kiraz, 2003, 2005; McIntyre, Byrd, \& Foxx, 1996; Paker, 2000; Sosik \& Godshalk, 2000). It is known that improving school practices through qualitative improvements in practices of executives, who are among curriculum elements, in such research that can be defined as formal curriculum evaluation works depends on decisions to be made based on evidence and policies to be carried out in line with such decisions (Anderson \& Ball, 1978; Varış, 1999). Consequently, it is considered that it is possible to conduct evaluation about features of executives by detecting the 
changes in the expectations of pre-service teachers, which are one of the said traces on pre-service teachers, and some probable factors that may cause changes. Cronbach (2000) defines evaluation as acquisition and use of knowledge in order to make decisions about a curriculum. Furthermore, Cronbach (2000) states that there can be three different decisions for curriculum evaluation and argues that decision about curriculum process is related to "which teaching materials and/or methods are satisfactory and what should be changed". Similarly, Stufflebeam (2000) states that the structure of curriculum contains many components and process evaluation is used to detect the reality between what is determined at the beginning and what is taking place at the moment. Payne (1973) states that teaching can be raised to the highest level through periodical evaluation of the process examined via formative evaluation and arrangement of learning experiences in accordance with outcomes. This study aims to define the options for decision makers about what they can do (what they must do) for developing practices by using the expectations of pre-service teachers in school practices. In this context, answers are sought to the following questions: 1) How do the expectation levels of pre-service teachers change during the process and is there a statistically significant difference between measurement levels? 2) What are pre-service teachers' opinions about realization of their expectations during school practices?

\section{Method}

The study was carried out using the split-plot design. Qualitative and quantitative methods were used together in the study which bears the qualities of a survey model as it is aimed at describing the expectations of pre-service teachers (Büyüköztürk, Çakmak, Akgün, Karadeniz, \& Demirel, 2009).

\subsection{Study Group}

The study group was selected in accordance with the convenience sampling method. This was affected by the fact that the researcher was abroad during some part of the data collection process (Büyüköztürk et al., 2009). The study group consists of 55 senior science teaching students from the faculty of education of a metropolitan university and 35 of them are females. The study, where participation was voluntary, was conducted with 44 pre-service teachers 27 of whom were females due to the fact that 5 pre-service teachers filled the scale incompletely, and 6 pre-service teachers did not attend sub-tests and posttests. The name of the faculty is not disclosed in order to prevent unfavorable opinions about the institution.

\subsection{Data and Data Collection Tools}

A few solutions were developed with the aim of providing data diversity in the study in order to obtain the expectations of the pre-service teachers in a valid and reliable manner (Yıldırım \& Şimşek, 2011). For this reason, the expectations of the pre-service teachers were first detected as quantitative data through a scale. Then focus group discussions were held with some of the pre-service teachers. Then a Scale for Expectations about School Practices was developed. Two kinds of research group were examined for that purpose. The first one is the examination of research focusing directly on the expectations of the pre-service teachers (Atputhasamy, 2005; Demirkol, 2004; Sağ, 2008). The second one is the research not focusing directly on expectations of pre-service teachers (Kiraz, 2003; Aytaç, 2010; Sağ, 2007).

It was tried to design the tool in a way that it can represent expectations of pre-service teachers about practice teachers and supervisors within the scope of School Experience and Teaching Practices. Thirty two items were defined for the tool where it was tried to communize their expectations from both kinds of personnel. Two instructors working at Curriculum and Teaching Departments in faculties of Educational Sciences were consulted regarding the content validity of the tool. The experts suggested that 3 items must be removed from the tool on the grounds that they were insufficient and the incoherency of two items needed to be corrected. The experts also suggested that it would be suitable to define the part of the tool enabling participants to express their opinions in a way that it is appropriate for all levels of measurement. Accordingly, it was decided to write "My Expectations" in the pretest, "The Existence of My Expectations" in the sub-test and "The Level at which My Expectations Have Been Realized” in the posttest in capital letters.

It was decided to define the graduation regarding the items in the tools prepared as a Five Point Likert Scale in a way that it is between "None (1)" and "Very High (5)". The pre-service teachers were asked to read especially the items in the middle of the form because the form would be applied once for both kinds of responsible 
personnel. Then they were asked to mark their evaluation about the practice teachers in the grading in the "Practice Teacher-Practice School" field on the left of the paper and their evaluation about the supervisors "Supervisors-Faculty of Education" on the right of the paper. Furthermore, an "implementer" that would stay with the pre-service teachers until the end of the practice was provided before every practice in order to give information to pre-service teachers about the aim of the tool in the current stage and concepts like "reflective thinking" as well as answering the questions of the pre-service teachers.

The works on the construct validity of the tool were performed with the data obtained through the practice teaching element. The trial form was applied to 175 pre-service teachers at senior classroom teaching, science teaching, and preschool teaching classes at the Faculty of Education at Mehmet Akif Ersoy University in 2010 2011 academic year. However, the construct validity of the tool was realized through the data of the remaining 146 forms. Construct validity, the Principal Components Statistics through explanatory factor analysis were used as well as the Varimax technique as it is assumed not to have strong relation between factors and as it is functional at the same time (Büyüköztürk, 2007; Field, 2006). The Keiser Meyer Olkin value of the tool is .91 and Barlett Alan Test valueis 2322.71 [BAT (df406), $p<.001$ ]. The fact that the communalities of the items included in the analysis are between .514 and .786 indicates that they have good values for analysis (Büyüköztürk, 2007).

In the first analysis of the tool, the Eigen value was equal to 1 and higher than 1 . It was also reported that the tool had 7 dimensions and the total variance was calculated as $67.2 \%$. The factor number was detected as 1 in the Scree Plot graphic. However, it is observed that expectations of pre-service teachers in the literature within the scope of school practices generally vary among three dimensions of professional guidance, collegiality and leadership and five dimensions in total including communication and evaluation. However, it is thought that the communication dimension can be defined within the collegiality dimension while the evaluation dimension can be defined as a function within the professional guidance and leadership. Therefore, the factor number was determined as three in the analysis and the analysis process was restarted. In that process, 8 items were removed from the analysis as the load value among the factors was below .10 (Büyüköztürk, 2007). As a result, a scale was developed where 21 items were gathered in three dimensions and the total variance expressed by it was $56 \%$. The reliability value of the scale was $(\alpha) .92$. The first factor with $(\alpha) .90$ reliability value consists of 9 items and its variance value is $23 \%$. The second factor with $(\alpha) .85$ reliability value consists of 8 items and its variance value is $21 \%$. The third factor with $(\alpha) .67$ reliability value consists of 4 items and its variance value is $11 \%$. The reliability values for each measurement level are as follows on dimension basis. The pretest reliability value of the scale is $(\alpha) .91$, the sub-test reliability value is $(\alpha) .95$, and the posttest reliability value is $(\alpha) .92$ for the practice teacher element. The pretest reliability value of the scale is $(\alpha) .94$, the sub-test reliability value is $(\alpha) .98$, and the posttest reliability value is $(\alpha) .81$ for the supervisor element.

The first factor was called collegiality as it defines professional relations. The second factor which is aimed to gain pre-service teachers the skills related to the informative dimension of the profession was defined as professional guidance. The third factor was called leadership as it is more about features that form the integrity of the teaching profession of pre-service teachers but do not stand out much and as it leads pre-service teachers (for the scale, see Appendix 1).

The second data collection stage of the research is to collect qualitative data. In this context, semi-structured focus group interviews were held with voluntary pre-service teachers at three measurement levels. In this sense, it is very important that the said technique "enables similar experience to make up for the insufficiencies of each other and to reveal their experience" and that "it has a fixed main theme but the details are based on the interview process" (Y1ldırım \& Şimşek, 2011). Six pre-service teachers 3 of whom were female participated in the interviews based on the focus group interview technique on a voluntary and regular basis. The pre-service teachers were asked to tell their expectations from the practice teacher and the supervisor about the practice school, the student, and the teaching profession at the very beginning of the School Experience lesson. In the second interview, the pre-service teachers were asked to evaluate their opinions about the realization of their expectations based on their experience. In the final interview, they were asked to define the level at which their expectations regarding their preparation for the profession through teaching practices and to tell their opinions about the factors related to the non-fulfillment of their expectations.

\subsection{Data Analysis}

Quantitative data was analyzed in two stages. First the normality levels of the data were studied in order to test the significance of the difference among the pretest, sub-test and the posttest. The Shapiro-Wilks statistic was 
used for that purpose as the number of the people in the group was less than 50 (Field, 2006). The analysis revealed that the data of both groups was non-normal and it was decided to use the ANOVA statistic of Friedman which is a one sided non-parametric test (Field, 2006). The Wilcoxon test which is a post hoc test was used for interrelated measurements to determine the source of significant differences in mean ranks revealed by the analysis. The significance level was dealt with in two different ways. The significance level was taken as .05 in the analysis used to look into the significance of the difference among interrelated measurements while the significance level was determined through the Bonferroni correction in the analysis about the source of the difference. Accordingly; .016 which was found by dividing the significance level .05 by 3 which is the number of the "pretest/sub-test", "pretest/posttest” and "sub-test/posttest” pairs $(.05 / 3=.016)$ was used. In this context, the significance of the $\mathrm{z}$ value obtained for each pair was interpreted depending on the fact that it was lower than .016 (Field, 2006; Laerd Statistics, 2013).

First the researcher transcribed the focus interview notes for the analysis of the qualitative data. The descriptive analysis technique was used in the research and meaning and integrity were obtained through codes and themes used for forming meaning relations among a lot of data (Yıldırım \& Şimşek, 2011). A series of methods were used in the research for analyzing the interviews and adapting to the quantitative data. The first one was giving the analyses in the form of chronological subheadings. The second one was interpreting the evaluations of the pre-service teachers on the basis of the expectation dimensions determined in the quantitative data. On the other hand, as the research was not a relational study, the explanations made in the interviews were not viewed directly as the source of change in the quantitative data. That is because no one-to-one correspondence was formed between the pre-service teacher from whom the data related to the change expectations were obtained and the pre-service teachers whose opinions about school practices were obtained. Furthermore, Miles and Huberman (1994) warn that the source of cause and effect implications in casual research in social fields such education might be multifaceted and therefore we should be careful with the subject of causal comments. Taking this warning into account, the researcher tried to make sure that the comments did not cause the readers to think that only the practice teachers and features depending on the practice teachers affected the realization levels of the expectations. There are many variables such as "school administration", "the attitudes and behaviors of other teachers towards pre-service teachers", "existence of policies reflecting the opinion of the faculty about the practices", and "the view of pre-service teachers about the teaching profession" directly or indirectly affecting the expectations of pre-service teachers.

\section{Findings}

\subsection{The Expectation Levels of Pre-Service Teachers during the Process}

\subsubsection{The Change of the Expectation Levels of Pre-Service Teachers during the Process (What, How?)}

This sub-problem was employed to examine the temporal course of the expectations of pre-service teachers about practice teachers and supervisors through the percentage (\%) statistic — due to lack of space-which is a descriptive statistic technique. Categories similar to one another in terms of meaning were interpreted together instead of five categories - even though data loss was experienced-while describing the expectation levels of pre-service teachers. It was thought that such definition would enable the readers to understand the findings more easily. Table 1 shows the information.

Table 1 shows that more than half (64\%) of the levels of expectations of pre-service teachers from practice teachers regarding the guidance dimension were high in the pretest while this value decreased in the sub-test (51\%) and was very low in the posttest (22\%). In the collegiality dimension, the number of the pre-service teachers with high levels of expectation was very high (85\%), the number of those whose expectations continued in the sub-test was still high (77\%) although there was a decrease, but the value was low in the posttest (29\%). It is observed that those with high expectation levels regarding the leadership dimension had a high value in the pretest (75\%), more than half (63\%) of them maintained their expectations although there was a decrease in the sub-test, but the value was low in the posttest (31\%).

Table 1 shows that the course of pre-service teachers' expectations about supervisors is mostly similar to the expectations about practice teaching although there is some difference. For instance, the rate of the pre-service teachers with high expectation levels in the pretest regarding the guidance dimension was a little higher than fifty percent (55\%) while this rate decreased in the sub-test (40\%) but the rate was not very low compared to the 
Table 1. Results of the descriptive analysis of the expectations of pre-service teachers about practice teachers and supervisors $(n=44)$.

\begin{tabular}{|c|c|c|c|c|c|c|c|c|c|c|c|c|c|c|c|c|}
\hline \multirow{4}{*}{ Group } & \multirow{4}{*}{ Factors } & \multicolumn{15}{|c|}{ Measurement Levels } \\
\hline & & \multicolumn{5}{|c|}{ Pre-test } & \multicolumn{5}{|c|}{ Sub-test } & \multicolumn{5}{|c|}{ Post-test } \\
\hline & & VHL $^{*}$ & HL & ML & VLL & $\mathrm{NE}$ & VHL & HL & ML & VLL & $\mathrm{NE}$ & VHL & HL & ML & VLL & NE \\
\hline & & $\%$ & $\%$ & $\%$ & $\%$ & $\%$ & $\%$ & $\%$ & $\%$ & $\%$ & $\%$ & $\%$ & $\%$ & $\%$ & $\%$ & $\%$ \\
\hline \multirow{4}{*}{$\begin{array}{l}\text { Practice } \\
\text { Teacher }\end{array}$} & Guidance & 34.9 & 29.5 & 25.0 & 8.5 & 2.0 & 21.6 & 29.0 & 33.8 & 12.8 & 2.8 & 6.0 & 16.2 & 39.8 & 26.1 & 11.9 \\
\hline & Collegiality & 58.8 & 26.2 & 8.1 & 5.0 & 1.3 & 50.5 & 26.0 & 15.9 & 5.5 & 2.0 & 14.4 & 24.8 & 33.3 & 21.0 & 6.3 \\
\hline & Leadership & 45.5 & 29.6 & 16.5 & 6.2 & 2.3 & 27.3 & 35.2 & 26.2 & 10.2 & 1.2 & 11.4 & 19.3 & 35.8 & 26.1 & 7.4 \\
\hline & Scale & 47.2 & 28.1 & 16.9 & 6.9 & 3.6 & 35.1 & 28.9 & 24.7 & 9.2 & 3.8 & 11.1 & 20.5 & 36.3 & 23.9 & 9.1 \\
\hline \multirow{4}{*}{ Supervisor } & Guidance & 23.0 & 31.5 & 25.0 & 12.5 & 7.1 & 14.2 & 25.6 & 22.2 & 20.5 & 16.8 & 16.8 & 20.5 & 32.7 & 20.2 & 6.1 \\
\hline & Collegiality & 46.5 & 31.1 & 14.9 & 3.7 & 3.8 & 35.8 & 31.3 & 12.6 & 6.3 & 13.9 & 7.3 & 30.5 & 49.8 & 9.6 & 2.8 \\
\hline & Leadership & 35.2 & 25.6 & 19.3 & 10.8 & 7.4 & 18.2 & 28.4 & 21.0 & 16.5 & 15.3 & 5.7 & 28.4 & 43.2 & 14.8 & 0.8 \\
\hline & Scale & 35.4 & 30.2 & 19.6 & 8.6 & 5.7 & 24.2 & 28.6 & 17.9 & 13.6 & 15.3 & 10.6 & 26.3 & 42.0 & 15.3 & 10.5 \\
\hline
\end{tabular}

"VHL: Very High Level; HL: High Level; ML: Medium Level; VLL: Very Low Level; NE: I Have No Expectation.

previous level in the posttest (37\%). The rate of the pre-service teachers with high expectation levels were very high (78\%) in the pretest regarding collegiality, this rate remained high (67\%) in the sub-test although there was a decrease, but the rate dropped in the posttest (38\%). Furthermore, the rate of the pre-service teachers with high expectation levels in the pretest regarding leadership was higher than fifty percent (61\%), the rate decreased but still approximately half of the pre-service teachers (47\%) maintained their expectations in the sub-test, but the rate was low (34\%) in the posttest.

\subsubsection{The Significance of the Changes in the Expectations of Pre-Service Teachers}

This stage deals with whether the said difference among the measurement levels of pre-service teachers' expectations is significant in statistical terms and the direction of the difference. The problem will be examined in two stages in terms of the total points obtained from the scale and the dimensions constituting the scale.

Examination of the temporal change of the expectations on scale basis: First the significance and direction of the changes in the expectation points of the pre-service teachers in process stages were looked into. Table 2 shows the information revealed by the analysis.

Table 2 shows that there is a significant difference among the pretest, sub-test and posttest mean ranks of preservice teachers' expectations regarding practice teaching $\left[\chi^{2}=22.57, p<.05\right]$. Median values were determined for each measurement in order to see the pairs among which there is a significant difference. Significant difference was observed between the pretest and the posttest $(Z=5.17, p<.016)$ and between the sub-test and the posttest $(\mathrm{Z}=4.17, p<.016)$.

Table 2 also shows that there is a significant difference among the pretest, sub-test, and posttest points of preservice teachers' expectations regarding practice teacher $\left[\chi^{2}(2)=19.17, p<.05\right]$. It is understood that the first difference is between the pretest and posttest and in favor of the pretest $[Z=2.81, p<.016]$ while the second difference is between the sub-test and posttest and in favor of the sub-test $[Z=3.70, p<.016]$. As a result, it is understood that the level of pre-service teachers' expectations about both practice teachers and supervisors decrease in time during school practices. Considering this result, we can say that the expectations of pre-service teachers about practice teachers and supervisors who provide professional guidance for them during school practices are not realized.

Examination of the changes in pre-service teachers' expectation points in terms of dimensions: Table 3 shows the information obtained through the analysis.

The information in Table 3 shows that there is a significant difference among the pretest, sub-test and posttest points showing the expectations of pre-service teachers from practice teachers regarding the "guidance" dimension $\left[\chi^{2}(2)=27.42, p<.05\right]$. The investigation of the source of difference revealed significant difference between the pretest and posttest expectation points in favor of the pretest $(Z=4.96, p<.016)$ and between the subtest and the posttest points in favor of the sub-test $(Z=3.87, p<.016)$. 
Table 2. ANOVA statistics analysis of Friedman for changes in expectation points.

\begin{tabular}{|c|c|c|c|c|c|c|c|c|}
\hline Groups & Measurements & $\mathrm{n}$ & Arithmetic mean & Mean rank & Sd & $\chi^{2}$ & $p^{*}$ & Significant difference ${ }^{* *}$ \\
\hline \multirow{3}{*}{$\begin{array}{l}\text { Practice } \\
\text { Teachers }\end{array}$} & Pre-test & 44 & 86.57 & 2.40 & \multirow{3}{*}{2} & \multirow{3}{*}{22.57} & \multirow{3}{*}{.001} & \multirow{3}{*}{$1-3,2-3$} \\
\hline & Sub-test & 44 & 80.95 & 2.17 & & & & \\
\hline & Post-test & 44 & 65.14 & 1.43 & & & & \\
\hline \multirow{3}{*}{ Supervisors } & Pre-test & 44 & 79.82 & 2.50 & \multirow{3}{*}{2} & \multirow{3}{*}{19.17} & \multirow{3}{*}{.001} & \multirow{3}{*}{$1-2,1-3$} \\
\hline & Sub-test & 44 & 70.34 & 1.92 & & & & \\
\hline & Post-test & 44 & 67.61 & 1.58 & & & & \\
\hline
\end{tabular}

Table 3. ANOVA statistics analysis of Friedman for changes in expectation points regarding professional guidance dimensions.

\begin{tabular}{|c|c|c|c|c|c|c|c|c|c|}
\hline Groups & Dimensions & Measurements & $\mathrm{n}$ & Arithmetic mean & Mean rank & Sd & $\chi^{2}$ & $p$ & Significant difference \\
\hline \multirow{9}{*}{$\begin{array}{l}\text { Practice } \\
\text { Teaching }\end{array}$} & \multirow{3}{*}{ Guidance } & Pre-test & 44 & 31.00 & 2.47 & \multirow{3}{*}{2} & \multirow{3}{*}{27.42} & \multirow{3}{*}{.01} & \multirow{3}{*}{$1-3^{*}, 2-3$} \\
\hline & & Sub-test & 44 & 28.27 & 2.14 & & & & \\
\hline & & Post-test & 44 & 22.25 & 1.40 & & & & \\
\hline & \multirow{3}{*}{ Collegiality } & Pre-test & 44 & 39.05 & 2.38 & \multirow{3}{*}{2} & \multirow{3}{*}{27.11} & \multirow{3}{*}{.01} & \multirow{3}{*}{$1-3,2-3$} \\
\hline & & Sub-test & 44 & 37.64 & 2.24 & & & & \\
\hline & & Post-test & 44 & 29.84 & 1.39 & & & & \\
\hline & \multirow{3}{*}{ Leadership } & Pre-test & 44 & 16.52 & 2.43 & \multirow{3}{*}{2} & \multirow{3}{*}{19.54} & \multirow{3}{*}{.01} & \multirow{3}{*}{$1-3,1-2,2-3$} \\
\hline & & Sub-test & 44 & 15.05 & 2.05 & & & & \\
\hline & & Post-test & 44 & 13.05 & 1.52 & & & & \\
\hline \multirow{9}{*}{$\begin{array}{l}\text { Practice } \\
\text { Instruction }\end{array}$} & \multirow{3}{*}{ Guidance } & Pre-test & 44 & 28.07 & 2.31 & \multirow{3}{*}{2} & \multirow{3}{*}{7.35} & \multirow{3}{*}{.03} & \multirow{3}{*}{$1-3$} \\
\hline & & Sub-test & 44 & 23.95 & 1.76 & & & & \\
\hline & & Post-test & 44 & 25.11 & 1.93 & & & & \\
\hline & \multirow{3}{*}{ Collegiality } & Pre-test & 44 & 37.05 & 2.49 & \multirow{3}{*}{2} & \multirow{3}{*}{26.02} & \multirow{3}{*}{.01} & \multirow{3}{*}{$1-3$} \\
\hline & & Sub-test & 44 & 33.20 & 2.08 & & & & \\
\hline & & Post-test & 44 & 29.70 & 1.43 & & & & \\
\hline & \multirow{3}{*}{ Leadership } & Pretest & 44 & 14.70 & 2.35 & \multirow{3}{*}{2} & \multirow{3}{*}{8.43} & \multirow{3}{*}{.02} & \multirow{3}{*}{$1-3$} \\
\hline & & Sub-test & 44 & 13.18 & 1.83 & & & & \\
\hline & & Posttest & 44 & 12.80 & 1.82 & & & & \\
\hline
\end{tabular}

Table 3 shows that that there is a significant difference among the pretest, sub-test and posttest points showing the expectations of pre-service teachers from practice teachers regarding the "collegiality" dimension just like in the "guidance" dimension $\left[\chi^{2}(2)=27.11 p<.05\right]$. The significant difference was observed between the pretest and posttest $(\mathrm{Z}=4.77, p<.01$ and between the sub-test and posttest $(\mathrm{Z}=4.26, p<.016)$.

The same table shows that that there is a significant difference among the pretest, sub-test and posttest points showing the expectations of pre-service teachers from practice teachers regarding the "leadership" dimension $\left[\chi^{2}(2)=19.54, p<.05\right]$. The significant difference was observed in all three pairs; between the pretest and subtest $(Z=2.57, p<.01)$, between the pretest and posttest $(Z=4.33, p<.016]$ and between the sub-test and posttest $(Z=2.60, p<.016)$.

The second part of Table 3 is related to the change among the expectation points of pre-service teachers about practice instruction in the "guidance" dimension. Accordingly, a significant difference is observed among the pretest, sub-test, and posttest points of pre-service teachers' expectations regarding the guidance dimension of practice instruction $\left[\chi^{2}(2)=7.35, p<.05\right]$. The investigation of the source of difference revealed a significant difference between pretest expectation rank scores $(Z=3.11, p<.016)$. 
A similar result is observed in the expectations of pre-service teachers from supervisors in the "collegiality" dimension. A significant difference is observed among the pretest, sub-test and posttest points of collegiality expectations of pre-service teachers $\left[\chi^{2}(2)=26.02, p<.05\right]$. The significant difference was observed in the expectation rank scores between the pretest between the pretest and posttest $(\mathrm{Z}=4.48, p<.016)$.

Table 3 also reveals a significant difference among the pretest, sub-test, and posttest points of "leadership" expectations of pre-service teachers regarding supervisors $\left[\chi^{2}(2)=8.43, p<.05\right]$. It is observed that the difference is between the pretest and posttest points in favor of the pretest $(\mathrm{Z}=2.43, p<.016)$.

Consequently, it is understood that there is a drastic decrease in the levels of pre-service teachers' expectation relating to both practice teachers and supervisors assigned to provide them with professional guidance during school practices. It can be said based on the range of the arithmetic means that the mentioned-above decrease takes place mostly in practice teaching. On the other hand, the results are far from providing opinions about the reasons of the expectation decrease. For this reason, the researcher wanted to examine the reviewing and opinions of the pre-service teachers about their experience in this process.

\subsection{Factors Affecting the Expectations of Pre-Service Teachers in the School Practice Process}

\subsubsection{School Experience}

It is thought that the impressions of the pre-service teachers in the first three weeks of the School Experience lesson had an integrated structure consisting of consecutive "first moments" and "adaptation to a new structure - getting familiar with the school operation and classroom organization" stages. It is thought that the first impressions of the pre-service teachers can be explained through the "satisfaction" theme in relation to the "appreciation/non-appreciation” belief based on this structure.

First moments: It is observed that impressions pre-service teachers have in their first experience can be "the moments when they are happy to be a teacher" for some teachers while they can be a "breaking point" for some. For instance, it is observed that pre-service teachers get satisfied when a meeting is held with the supervisors at the faculty where they are warned about the "dress code of the school" and told "what they are supposed to do at the school" and when "the group is accompanied on the first day of practice". Furthermore, it is understood that the warm welcoming of pre-service teachers at the practice school makes them happy to have the same profession. For instance, statements of pre-service teachers stating "Invitation by the vice principal, offering tea, introducing the school/having a meal together, introducing the pre-service teachers with the practice teachers, telling them that they are the teachers of the school now" can be given as examples.

On the other hand, it is understood that many pre-service teachers were not satisfied with their experience in these first moments. Pre-service teachers said "supervisors did not meet with them before the practices" and "they did not accompany them on the first day of practice" about the said experience. Only two of the six preservice teachers who were interviewed said that they had met with supervisors while the other four teachers said they had prepared for the first day without any briefing about what they would encounter at the practice school. It is observed that a similar problem takes place during first experience at practice schools. Pre-service teachers say "We just submitted the file (student attendance sheet file) to the vice principal and left" and "We directly went to the vice principal's room. Then we were introduced to our advisor (practice teacher) at the school. They did not show much interest" about their experience in this context.

Adapting to a new structure-getting familiar with the school operation and classroom organization: The second factor affecting pre-service teachers is "the reality of school and classroom organization". It is understood that pre-service teachers first go through a stage of "amazement" in relation to the school which is new to them, the operation of the school and the organization of classrooms where they will be teaching; then they shift to the "adaptation" stage in order to get rid of this situation. Pre-service teachers give the following examples for the circumstances that create amazement in them: "The student called them brother/sister for a few weeks./The children were happy to see the pre-service teachers and shouted "ah, the blonde teacher"./They witnessed inclusive education performed for teaching disabled students. However, they state that the amazement did not last long and they started to adapt to being a teacher. For instance, this can be understood from the following statements of the pre-service teachers: "We became actual teachers after you teach lessons during the first week./You start to work as a teacher (you feel like a teacher). You think about what you should do in the lesson, how you should treat the subject and you start to get used to the noise in classrooms”. 
It is observed that the most challenging part for pre-service teachers in this process is adaptation to the said new organization. It is understood that this fact creates a serious need in pre-service teachers for professional guidance services. As a matter of fact, the following statements of the pre-service teachers reveal that they did not receive such professional guidance: "I expect psychological and educational guidance services. Psychological guidance must be provided about the possible behaviors and reactions of students./Teachers, students, principals can be introduced to us. But we didn't receive such services. I think we did not receive any guidance services. Some services could have been provided in the form of orientation such as 'This is your school, your students are like this'./We started teaching as soon as we entered the classroom. But we could have been given information about what had to be done exactly and what we would encounter.”

\subsubsection{Transition from School Experience to Teaching Practice}

The pre-service teachers were asked to tell their impressions about their experience in the first weeks after they started the Teaching Practice lesson. The impressions revealed in those interviews can be gathered under the following topics: "having difficulties due to the complexity of the profession" and "isolation depending on the nature of social relations".

Having difficulties due to the complexity of the profession: One of the pre-service teachers said s/he had 12 course hours of teaching experience, another teacher reported that s/he solved some problems from time to time and had 10 - 15 minutes of teaching experience when the teacher went somewhere, another teacher said s/he had 6 - 7 course hours of teaching experience within that period. Considering the diversity of teaching experience, the pre-service teachers said the following about practices: "We prepared a symbolic plan/The practice teacher leaves the planning to us. S/he usually mails us the subject we are supposed to teach but s/he leaves the contents to us. We teach the subject in front of the class."

The pre-service teachers reported that they were not very satisfied with their first teaching experience because they had a lot of difficulties within that period. It is understood that the pre-service teachers needed intense guidance on subjects that created difficulties for them in that stage. The pre-service teachers state the difficulties they had regarding this matter and the reasons for those difficulties as follows: "I could not teach the way I wanted because it is really hard to teach by taking all differences into account within a course hour./Each class has its own characteristics. I try to imagine that I can but it does not work./We prepared a subject and presented it for 45 minutes (in the special teaching methods course last semester). We thought our friends here (meaning pre-service teachers) as 6th, 7th, and 8th grade students and everyone who came to the blackboard or was allowed to speak already knew their assignment. The whole class taught in this way. But now the classes have 20 25 students. It is very hard to teach children that do not know and to do the same activities with them. But no, it is really very difficult./I think we also deal with genetics, anatomy etc. It is like a higher level. When you go there, you start to think how you could teach this at the children's level. You can teach in a more complicated manner there (meaning the faculty) even though it is not necessary at all."

Isolation level depending on the nature of social relations: Another subject brought forward by the pre-service teachers is their impression about the effects of the attitudes and behaviors of the practice teachers and other teachers, especially other practice teachers in the same branch. Attitudes and behaviors where social relations are dominant stand out in the pre-service teachers' impressions within the scope of collegiality. For instance, the following statements are examples of this fact: "The teachers just passed by us without paying any attention. They made us feel redundant./They did not make us feel like teachers, nor did they show any intimacy./Only the students regarded us as teachers./There are three science teachers. I was walking with the male teacher. The female teacher intercepted us and asked: 'Isn't anyone teaching me this week?' The general attitudes of the teachers are as follows: 'They will teach the lesson so that we can deal with other things'... They don't take us much seriously./We do not enter the teachers' lounge much... We don't know how they will react in this unfamiliar environment./Another science teacher at the school saw us as rivals. We were scolded badly. We had made the students perform a team effort. The teacher scolded us by saying 'You must not do anything during this semester.' We were very surprised to see that the teacher discouraged us instead of encouraging. That situation had a great effect on me when I went to school a week later./Nobody said 'The interns are here, let's meet them' I still could not go to the teachers' lounge. I could not understand whether we were teachers.”

On the other hand, some of the pre-service teachers were quite satisfied with the attitudes and behaviors of the practice teachers towards them. It is observed that the said favorable attitudes and behaviors caused the pre-service teachers to feel closer to the teachers and become happy to be with them as opposed to the previous situa- 
tion. The pre-service teachers state the favorable attitudes and behaviors as follows: "When we come across the teachers in hallways, they share their experience every now and then./Some teachers tell us to help ourselves to some tea. One day I was eating a donut. The teacher offered me tea saying 'Go get some tea'./We enter the teachers' lounge as a group of six people. This is very crowded for the little teachers' lounge. We went there in the breaks. For instance, there is a Turkish language teacher. He offers all of his professional knowledge. He says 'You must be harsh and sweet at the same time. Students must notice when you come in. But you must do this without frightening them'.”

\subsection{Teaching Practice Evaluations}

In this interview which was held towards the end of the academic year, the pre-service teachers were asked to evaluate the teaching practices within the framework of their impressions. They were requested to base their evaluations on the levels at which their expectations came true in terms of feeling ready for being a teacher. This part was designed to include "satisfaction based on realization of expectations" and "dissatisfaction based on non-realization of expectations".

Satisfaction based on realization of expectations: Some pre-service teachers who stated that their expectations had come true listed those expectations as "gaining experience", "teaching children alone in the class", "communicating with students", "learning the operation of the school”, "transfer of experience by teachers", "establishing dialogs outside the classroom", "sharing problems without hesitation" and "receiving professional inspiration". The statements contain "realization of expectations" and "satisfaction monitoring” generally as a whole and the sentences were not separated in order to understand the relationship between them better. Accordingly, the pre-service teachers stated both their expectations that came true and their satisfaction impressions based on that fact as follows: "Even though I cannot say I learned every aspect of the teaching profession, I can say that I gained significant amount of experience./Most of my expectations at the beginning of the year have been met; it was good to teach lessons on my own in the classroom, to communicate with the students, to learn the organization and operation of the school. I should say that especially the internship practice teacher was very helpful. S/he shared his/her experience, gave me advice on what I should do and how I should do it in the lessons, also we could share our problems outside the class without hesitation as we established a good dialogue outside the classroom, s/he helped me very much./The teaching profession is a dynamic profession that is constantly changing together with content knowledge, teaching methods, and many improving innovative approaches. Consequently, I have learned the first thing about teaching. There is still a lot for me to learn and update: both the students I taught and the teachers whose lessons I attended were a source of inspiration for me.

Dissatisfaction based on non-realization of expectations: On the other hand, some of the pre-service teachers said that their expectations had not come true. These pre-service teachers stated the expectations that did not come true, the reasons for this non-realization as well as their dissatisfaction as a whole as in the previous situation. Here the statements of the pre-service teachers were not separated, they were given as a whole as "the expectations that were not met" and "the reasons". The pre-service teachers made the following statements about this fact: "The other science and technology teacher working at the school sometimes behaved in a manner that made us feel that the teacher despised us and did not take us seriously./I believe the teaching profession cannot be learned by making a few hours of observation or receiving theoretical education for four years. Neither the school nor the internship practices had any effect on learning the profession. Observing the actions of the advisor in limited time and doing some works that can be called "drudgery" will not teach us how to be a teacher. I don't think one can learn the teaching profession without experiencing it./I don't think it is possible to learn the teaching profession by obtaining theoretical knowledge and putting it into practice right away. I think one must gain some experience in the profession. I learned some things about the lecturing part of the teaching profession but I could not learn anything about other duties of teachers such as preparing plans, curriculum etc. My expectations have not been met completely. We just watched as we were kept in the background. Most things went unlearned."

The pre-service teachers list the factors that prevented their expectations from being met as follows: problems stemming from lack of cooperation between the faculty and the practice school, the indifference of the supervisors, the ignorance and indifference of the practice teachers, the attitude of the practice school towards the preservice teachers. The pre-service teachers made the following statements on this matter: "I would rather they had done more and regular meetings. The agenda of these meetings could have been determined collectively by us 
and the faculty practice teacher (meaning the supervisors); various briefings could have been held, the internship period could have been evaluated, and problems could have been solved instantly./We take tough courses until the 3rd grade but I believe it would be better if we received education in cooperation with the school (meaning the practice school) in the courses we take in the 3rd grade. Otherwise a disconnection emerges./The practice teacher and the supervisor here must work coordinately. We learn less even though we could at least see many things we overlook in our natural and ordinary observations if we went prepared./We only go there one day a week. We don't know the name of the students. We cannot spend time with them./In my opinion, the biggest insufficiency of school practices is the fact that there is little communication between the advisor at the university and the teacher at the school and the lack of a plan. In other words, our advisor at the university should tell the teacher at the school what we are supposed to learn on a weekly basis and we should make observation in line with the determined plan when we go to our school. My insufficiency is that I did not pay due attention. That is because I am not used to teach without a plan./Only one teacher made the following evaluation: 'You will become a great teacher, we got high efficiency from you. Teach the next lesson.'/The teacher made me teach for 4 hours. He asked 'How did you find yourself?' (Then he said) 'You were constructivist in the first lesson but you shifted to the traditional method afterwards.' The pre-service teacher was asked whether the teacher provided satisfactory information for preliminary preparation before and after lessons. The answer was as follows: "No, he just said that but the children did not participate either. You are right./We observe by ourselves. As a result, I can benefit little by little, I cannot concentrate completely."

On the other hand, the pre-service teachers state that they came across bad incidents that had a negative effect on them during the school practices and that they found those incidents odd. The pre-service teachers said the following about those incidents and why they found them odd: "It had a great effect on me to see the teacher at the practice school inflict violence on a girl. I don't think a little child deserves to be beaten under any circumstances. That incident alienated me from the practice school. I was very reluctant to go there after that day./ Scolding students in classroom or embarrassing them are some of behaviors I don't approve of. The fact that the students were extremely afraid of the teacher and the principal, that the teacher called 5 - 6 students who had escaped from the national anthem ceremony to the board and treated them like traitors and punished them are some incidents that surprised me./The teacher was very harsh and yelled at the students from time to time.”

\section{Discussion}

Although the expectation concept is not directly related to curriculum development and evaluation, rather it is considered for development of tutorial programme then to have been put forth from 90's (Sander, 2006; Sander et al., 2000; Stevenson et al., 1997) when it functioned as a new instrument such as learning outcomes. In spite of the fact that a lot of factors had an impact on the emergence of such researches, two basic factors are considered to have played an important role. Increasing democratic understanding is one of them (Hill, 1995). The other factor is considered to have emerged as a result of the idea which maintains that the curriculum conducted in line with the findings acquired by taking descriptive evaluation approach as a basis must develop the content and effectiveness of relevant curriculum as well as developing attitudes, manners and behaviors of the instructors against their students. In these research, expectation sources have been categorized in two groups as students (Sağ, 2008; Atputhasamy, 2005; Demirkol, 2004) and supervisors (and/or other educationists) (Demirkol, 2004; Sander et al., 2000).

In addition to this, some points are deemed necessary to be kept in mind while using the concept "expectation" in such researches. One of them is not to limit the expectation source to one group. The expectation concept related to the teaching profession which is examined in this research is considered to provide content validity by including the other source group into the research which now constitutes a deficiency. Another issue to be taken into consideration with regard to this subject is related to the psychological structure of the expectation concept. In the researches they conduct about consumer expectations, Zeithaml, Berry, and Parasuraman, (1993) warn that "consumers tend to seem as if their expectations are met at a low level even if they like products". The main emphasis made here is that; ensuring harmony between the sufficiency levels of pre-service teachers' perceptions and the activities included in curricula or the sufficiency levels of the attitudes and behaviors performed against pre-service teachers is a serious problem. As a result, the researchers who will conduct such researches taking expectation concept as a basis are recommended to take data diversity into account in addition to expectation sources, the expectation concept and other data sources during the development and evaluation of curricula. 
In this research that it is understood that the highest expectation of pre-service teachers from both attendants is the "collegiality role" which is followed by "leadership" and "guidance" roles. Pre-service teachers' expectation levels are higher in practice teachers than in supervisors. This is highly remarkable considering the fact that the expectation level for guidance roles is higher in practice teachers than in supervisors. It is also observed that the leadership role is preferred before the guidance role. The researcher attributes this result to some important reasons and thinks it can be understood from students' impressions. As a matter of fact, it is observed that the interactions that must be directly or indirectly established by pre-service teacher at the very beginning of the school experience lesson with the said two responsible personnel and other people involved in school practices regarding "first meeting" and "satisfaction of their need to adapt to the school" had a great effect.

At the end of School Experience lesson, grades related to pre-service teachers' maintaining their expectations were determined to decline dramatically at the mid-term measuring level. The high expectation level which preservice teachers had against those two responsible personnel at the beginning as they thought they would prove effective in helping them orientate themselves to an unknown structure turns during the mid-term into low expectation level. This change is assumed to have some reasons. First one of them is related to the breaking points which pre-service teachers went through in practice school and the professional guidance services they got at these moments. These reasons consist of their first day experiences, "being shocked" against what they see as they couldn't anticipate them and "being afraid of" giving lessons in a complicated classroom. In this practice, "briefings given to pre-service teachers by the instructors before they go to the school", the school management they encounter in the practice school and the good-humored approach showed to them during first meeting as well as the fact that the practice teachers in addition to other teachers regard them as teachers have been observed to have an impact on pre-service teachers' impressions. It is also seen that collegiality expectations are very important for pre-service teachers so that they can get rid of any shock situation by trying to understand what is going on around them without getting flurried and so that they can feel self-confidence instead of fear. Another supporting finding in this subject is thought to put forward the collegiality role including the attitudes, manners and behaviors which makes it easy for pre-service teachers to orientate themselves to a new and different socio-cultural structure.

When we look into the realization level of expectations at the end of Teaching Practice, the situation does not seem so good. For instance, guidance expectations have the lowest realization level in practice teaching which is followed by collegiality expectations, and leadership expectations. Although the curve in supervisors is a bit different from practice teachers, it doesn't decrease very much. However, this situation doesn't result from the realization of the expectations against supervisors. It results from the fact that pre-service teachers regard this group as non-functional. Pre-service teachers state that they are negatively affected by some actions of other practice teachers who work in the same branch with their practice teachers. These are "making pre-service teachers do some works which they must do themselves", "their discouraging talks about the teaching professsion", "making pre-service teachers do some chores" and "the attitudes and manners displayed against them within the school, in corridors etc." On the other side, it is understood that some pre-service teachers were positively affected as practice teachers "are participative", "create time for ensuring association" and "other teachers share their professional experiences with pre-service teachers since they see them as their colleagues". Another issue to be mentioned here consists of the impressions created on pre-service teachers by the quality of such attitudes, manners and behaviors performed by school managers and other teachers especially the practice teachers against pre-service teachers throughout the academic year. Pre-service teachers feel satisfied when their expectations are met. They state affection and good-humored behaviors make them feel valuable. In addition to this, they state to feel unsatisfied when their expectations are not met while also stating that they feel worthless when other teachers display cold behaviors, beneficiary approaches and make them do chores.

It is observed in the last stage that the realization levels of pre-service teachers' guidance expectations are highly low especially against practice teachers. Here, the most important situation is thought to be related to the fact that "pre-service teachers feel uncertain about what to do against the complexity of teaching profession" and "they are left alone in this issue". Pre-service teachers claim the teaching process to be complicated because they also claim "managing a classroom consisting of the pre-service who have many different features, using time in an efficient way and adopting subject-related information to the class level" pose them difficulties. Pre-service teachers think this is because "information about the discipline is at the high level" and "teaching methods are applied in an artificial atmosphere". Pre-service teachers state that the said "adaptation" issue is highly problematic and they can't get the guidance service which they need during this adaptation period. 
While pre-service teachers put forward expectations about professional guidance in quantitative researches (Atputhasamy, 2005; Çelikkaya, 2012; Demirkol, 2004), in qualitative researches in which pre-service teachers are not directed, they highlighted the quality of relations with practice teachers within the scope of collegiality, their evaluation and classroom management (Paker, 2011; Să̆ , 2008). As can be seen in research (Beck \& Kosnik, 2002; Sağ, 2008; Zeichner, 2002) pre-service teachers' expectation about orientating themselves to the school which is a new socio-cultural structure for them emerges as a priority. However, as observed in this research, some researchers state that meeting such expectations may not be at desired level (Borko \& Mayfield, 1995; Trevethan, 2013; Zeichner, 2010). For instance, it has been observed that practice teachers did not care enough, and therefore, some of the pre-service teachers experienced loneliness, worthlessness and eventually dissatisfaction. As Borko and Mayfield (1995) and Trevethan (2013) state it is thought that one of the reasons for this may be that some practice teachers and supervisors identified their status towards teacher training beyond pre-service teachers' expectations. This approach may lead to serious problems in allocating time for pre-service teachers and setting an effective feedback system. One of them, as seen in the findings of this research, is the existence of a superficial assessment rather than an effective evaluation (Borko \& Mayfield, 1995). Zeichner (2010) claims that there is an inconsistency problem between both sides in terms of epistemology. Therefore it is not easy to establish a link between them.

It is seen that another factor in the decline of expectations is that the skills that pre-service teachers gain in the scope of teacher training at university do not match the teaching practices at practice school. In fact, contemporary cognitive learning researchers (Eysenck \& Keane, 2003; Brophy, 1982) suggest teaching cannot be independent from the structure, and for this reason, different structures requires different learning styles. The cognitive researchers evaluating this with social dimensions of learning identify learning and teaching process which requires interaction as a cultural activity. Proceeding from here, as Borko, and Mayfield (1995) assert it is not possible that pre-service teachers can teach at real school atmosphere with the skills that they obtained at practice schools where they practiced in university years. This is because the school atmosphere, pre-service characteristics, lesson plans and physical conditions are different from that of these pre-service teachers' experience at university. Thus, Borko and Putnam (1996) denote that in order that pre-service teachers can become better teachers the people who are assigned to supervise them should back up them in a way that they can discover new teaching methods, should set feedback system for teaching practices and should meet their expectation of emotional support.

One of the key points in school practice is pre-service teachers' emotional worlds which cause their expectations decrease or remain at high level. Goleman (2013) emphasizing the error of handling learning just as a cognitive dimension states that "this approach is a distorted scientific view which has directed the researches on intelligence, and has dreamt a monotonous cognitive life in terms of emotion” (p. 71). Thus, it has been put forth in the researches carried out with pre-service teachers that not only pre-service teachers but also all participants experienced intensive emotions (Mapfumo, Chitsiko, \& Chireshe, 2012; Sumsion, 1998; Trevethan, 2013). Mapfumo et al. (2012) state that the anxiety level of pre-service teachers about "not being successful" and "getting low mark in the assessment" is high, and this causes them to get stressed. Similarly, Sumsion (1998) put forward that pre-service teachers' experience an affective intensity which is effected by the concern of being unable to meet high expectations. It can be said that the existence of these negative emotions can be a noticeable variable in the quality decrease of school practices.

When findings are evaluated in terms of the location where this study has been made, it can be said that important results may occur if decision makers who are responsible for performing the lessons included in school practices takes following precautions:

Beginning phase: The climate in the practice school where pre-service teachers are placed as well as the attitudes, manners and behaviors of practice teachers are highly effective on pre-service teachers. This is because pre-service teachers experience some problems in adapting themselves to the school institution which is a new social and physical structure; and first moments and first meetings are highly important as they constitute the very first steps. This can be discussed with practice school coordinators and practice teachers under the coordination of education faculty. Accordingly, new approaches for better atmosphere can be created and applied.

Interim Phase: It is observed that pre-service teachers have difficulties in adapting to the real life such information, skills and approaches which they learn during the pre-service training. It is understood in this phase that the period during which pre-service teachers' theoretical information is turned into practice requires intense guidance and leadership services. It is observed that the collegiality relation constituting the keystone of this 
phase determines also the whole process. Short time effective in-service training seminars can be organized for practice teachers and supervisors to use such techniques as clinic supervision and reflective teaching. With the help of these techniques, it can be easily understood in which areas pre-service teachers need professional guidance; moreover, their self-awareness can be promoted.

Ending phase: Especially practice schools are observed to be problematic in terms of the facts that their organizational climates don't approve pre-service teachers and practice teachers and supervisors have problems while fulfilling their collegiality and guidance services. This issue must be discussed with practice schools under the coordination of faculty practice schools and the directorate of national education.

\section{Conclusion}

Although teacher candidates had very high expectations towards both groups, there occurred a dramatic decrease especially in practice teaching roles in time. This decrease was observed in collegiality, leadership and guidance roles respectively. It is thought that some illuminating clues concerning the reasons for this decrease were obtained in these interviews. These can be ranked as reluctance to getting acquainted with student teachers at the beginning, then being indifferent to them as their colleagues, not guiding them professionally during the practice and finally not providing them with an adequate professional guidance.

\section{References}

Anderson, S. B., \& Ball, S. (1978). The Profession and Practice of Program Evaluation. San Francisco, California: JosseyBass.

Atputhasamy, L. (2005). Cooperating Teachers as School Based Teacher Educators: Pre-Service Teachers’ Expectations. Australian Journal of Teacher Education, 30, 1-11.

http://ro.ecu.edu.au/cgi/viewcontent.cgi?article=1395\&context=ajte

Aytaç, A. (2010). Öğretmenlik Uygulaması Kapsamında Uygulama Öğretim Elemanlı̆̆ının Değerlendirilmesi. Master Thesis, Burdur: Mehmet Akif Ersoy University Social Sciences Institute.

Ball, D. L., \& Cohen, D. K. (1999). Developing Practice, Developing Practitioners: Toward a Practice-Based Theory of Professional Education. In G. Sykes, \& L. Darling-Hammond (Eds.), Teaching as the Learning Profession: Handbook of Policy and Practice (pp. 3-32). San Francisco: Jossey Bass.

Bandura, A. (1971). Social Learning Theory. http://www.esludwig.com/uploads/2/6/1/0/26105457/bandura_sociallearningtheory.pdf

Beck, C., \& Kosnik, C. (2002). Components of a Good Practicum Placement: Pre-Service Teacher Perceptions. Teacher Education Quarterly, 29, 81-98.

http://www.teqjournal.org/backvols/2002/29_2/sp02beck_kosnick.pdf

Bektaş, M., \& Ayvaz, A. (2012). The Expectations of Pre-Service Teachers about Teaching Practice. Mersin University Journal of the Faculty of Education, 8, 209-232.

Borko, H., \& Mayfield, V. (1995). The Roles of the Cooperating Teacher and University Supervisor in Learning to Teach. Teaching \& Teacher Education, 11, 501-518. http://dx.doi.org/10.1016/0742-051X(95)00008-8

Borko, H., \& Putnam, R. (1996). Learning to Teach. In D. Berliner, \& R. Calfee (Eds.), Handbook of Educational Psychology (673-708). New York: MacMillan.

Brophy, J. E. (1982). Research on the Self-Fulfilling Prophecy and Teacher Expectations. East Lansing: Michigan State University, Institute for Research on Teaching. http://files.eric.ed.gov/fulltext/ED221530.pdf

Büyüköztürk, Ş. (2007). Sosyal Bilimler Için Veri Analizi El Kitabı. Ankara: PegemA Yayıncılık.

Büyüköztürk, Ş., Çakmak, E. K., Akgün, Ö. E., Karadeniz, Ş., \& Demirel, F. (2009). Bilimsel Araştırma Yöntemleri. Ankara: Pegem Akademi Yayıncilık.

Calderhead, J. (1991). The Nature and Growth of Knowledge in Pre-Service Teaching. Teaching and Teacher Education, 7 , 531-535. http://dx.doi.org/10.1016/0742-051X(91)90047-S

Çelikkaya, T. (2011). Sosyal Bilgiler Öğretmen Adaylarının Öğretmenlik Uygulaması Dersinden Beklentileri ve Bu Beklentilerin Karşılanma Düzeyleri. Uluslararası Sosyal Bilimler Ĕgitimi Dergisi, 1, 155-172.

Coaldrake, P. (2002). Institutional Response to Changing Students Expectations: Project Overview. In Organisation for Economic and Co-Operation and Development (OECD) (Ed.), Responding to Students Expectation (pp. 7-17). http://www.keepeek.com/Digital-Asset-Management/oecd/education/responding-to-student-expectations_9789264176225 -en\#page3 
Cole, A. L., \& Knowles, J. G. (1993). Shattered Images: Understanding Expectations and Realities of Field Experiences. Teachrng \& Teacher Educarion, 9, 457-471. http://dx.doi.org/10.1016/0742-051X(93)90030-K

Cronbach, L. J. (2000). Course Improvement through Evalutaion. In D. L. Stufflebeam, G. F. Madaus, \& T. Kellaghan (Eds.), Evaluation Models: Viewpoints on Educational and Human Services (2th ed., pp. 235-247). Hingham, MA: Kluwer Academic Publishers, Inc.

Darling-Hammond, L. (2003). Keeping Good Teachers: Why It Matters, What Leaders Can Do? Educational Leadership, 60, 6-13.

Demirel, Ö. (1999). Kuramdan Uygulamaya Eğitimde Program Geliştirme. Ankara: Kardeş Kitap ve Yayınevi.

Demirkol, İ. (2004). Expectations for the Roles of Cooperating Teachers and University Supervisors during the PracticeTeaching Period as Perceived by University Supervisors, Cooperating Teachers and Preservice Teachers. Master Thesis, İstanbul: Boğaziçi University.

Doğan, H. (1997). Eğitim Programı ve Öğretim Tasarımı. Ankara: Önder Matbaacılık.

Ertürk, S. (1971). Eğitimde Program Geliştirme (8th ed.). Ankara: Meteksan Baskı A.Ş.

Eysenck, M. W., \& Keane, M. T. (2003). Cognitive Psychology (4th ed.). New York: Psycology Press.

Feiman-Nemser, S., \& Buchman, M. (1983). Pitfalls of Experience in Teacher Preparation. Occasional Paper: 65. East Lansing, MI: The Institute for Research on Teaching, Michigan State University. http://education.msu.edu/irt/PDFs/OccasionalPapers/op065.pdf

Field, A. (2006). Discovering Statistic Using SPSS (2nd ed.). London, Thousand Oaks, New Delhi: Sage Publications.

Gallagher, M. (2002). Encouraging University Responsiveness: Student-Focused Incentive in Australian Higher Education. In Organisation for Economic and Co-operation and Development (OECD), Responding to Students Expectation (pp. 85-101).

http://www.keepeek.com/Digital-Asset-Management/oecd/education/responding-to-student-expectations_9789264176225 -en\#page3.

Gerring, R. J., \& Zimbardo, P. G. (2012). Psikolojiye Giriş Psikolojive Yaşam (G. Sart, Trans.). Ankara: Nobel Yayınevi.

Goleman, D. (2013). Duygusal Zeka: Eq Neden IQ'dan Daha Önemlidir? (36th ed.). İstanbul: Varlık Yayınları.

Grossman, P. (2011). Framework for Teaching Practice: A Brief History of an Idea. Teachers College Record, 113, 28362843. http://www.tcrecord.org

Grossman, P., \& McDonald, M. (2008). Back to the Future: Directions for Research in Teaching and Teacher Education. American Educational Research Journal, 45, 184-205. http://dx.doi.org/10.3102/0002831207312906

Hastings, W. (2004). Emotions and the Practicum: the Cooperating Teachers' Perspective. Teachers and Teaching: Theory and Practice, 10, 135-148.

Hill, F. (1995). Managing Service Quality in Higher Education: The Role of the Student as Primary Consumer. Quality Assurance in Education, 3, 10-21. http://dx.doi.org/10.1108/09684889510093497

Ilyenkov, E. V. (1974). Activity and Knowledge. In E. V. Ilyenkov (Ed.), Philosophy and Culture.

http://www.marxists.org/archive/ilyenkov/works/activity/index.htm

Karasar, N. (2005). Bilimsel Araştırma Yöntemi. Ankara: Nobel Yayıncılık.

Kiraz, E. (2003). Uygulama Öğretmeni Yeterlilik Ölçeği: Ölçü Aracı Geliştirme Örneği. Türk Ĕ̆itim Bilimleri Dergisi, 1, 387-398.

Kiraz, E. (2005). Older Is Not Always Better: A Study of Novice and Experienced Teachers in Fulfilling Supervisory Role. In N. P. Terzis (Ed.), Quality in Education in the Balkans (pp. 509-523). 2-3 July 2004, Sofia, Bulgaria. Athens, Greece: Kyriakidis Publishing House.

Laerd Statistics (n.d.). Friedman Test in SPSS. https://statistics.laerd.com/spss-tutorials/friedman-test-using-spss-statistics.php

Ling, K. C. (2010). The “Inside-Out” and “Outside-In” Approachs On Students’ Perceived Services Quality: An Empirical Evaluation. Management Science and Engineering, 4, 1-26.

Mapfumo, J. S., Chitsiko, N., \& Chireshe, R. Teaching Practice Generated Stressors and Coping Mechanisms among Student Teachers in Zimbabwe. South African Journal of Education, 32, 156-166.

McIntyre, D. J., Byrd, D. M., \& Foxx, S. M. (1996). Field and Laboratory Experiences. In J. Sikula, T. J. Buttery, \& E. Guyton (Eds.), Handbook of Research on Teacher Education (2nd ed., pp. 171-193). New York: Macmillan.

Miles, M. B., \& Huberman, A. M. (1994). Qualitative Data Analysis (2nd ed.). London: Sage Publications Ltd.

Oliva, P. F. (2009). Developing the Curriculum (7th ed.). Boston, MA: Allyn \& Bacon, Inc.

Paker, T. (2000). Teaching Practice from Student Teachers’ Perspective. Çukurova Üniversitesi Sosyal Bilimler Enstitüsü 
Sosyal Bilimler Dergisi (Journal of Social Sciences), 6, 111-118.

Paker, T. (2011). Student Teacher Anxiety Related to the Teaching Practicum. Eğitim Araştırmaları-Eurasian Journal of Educational Research, 42, 207-224.

Parasuraman, A., Zeithaml, V., \& Berry, L. (1985). A Conceptual Model of Service Quality and Its Implications for Future Research. Journal of Marketing, 49, 41-50.

http://faculty.mu.edu.sa/public/uploads/1360593395.8791service\%20marketing70.pdf

Payne, D. A. (1973). Some Old and New Wives’s Tales Concerning Curriculum Evaluation. Educational Leadership, 30, 343-347. http://www.ascd.org/ASCD/pdf/journals/ed_lead/el_197301_payne.pdf

Rotter, J. (1966). Internal versus External Control of Reinforcement: A Case History of a Variable. http://mres.gmu.edu/readings/PSYC557/Rotter1990.pdf

Sağ, R. (2007). Öğretmen Ĕ̆itiminde Uygulama Öğretmenliği Uygulamasının Değerlendirilmesi. Ph.D. Thesis, Eskişehir: Anadolu University.

Sağ, R. (2008). The Expectations of Student Teachers about Cooperating Teachers, Supervisors and Practice Schools. Egitim Arastirmalari-Eurasian Journal of Educational Research, 32, 117-132.

Sander, P. (2006). Researching Our Students for More Effective University Teaching. Electronic. Journal of Research in Educational Psychology, No 5-3, 1, 113-130.

http://www.investigacion-psicopedagogica.org/revista/articulos/5/english/Art_5_36.pdf?origin=publication_detail

Sander, P., Stevenson, K., King, M., \& Coates, D. (2000). University Students’ Expectations of Teaching. Studies in Higher Education, 25, 309-323. http://dx.doi.org/10.1080/03075070050193433

Schilling, K. M. (1999). Increasing Expectations for Student Effort. About Campus, 4, 4-10.

Selçuk, Z. (2001). Okul Deneyimi ve Uygulama (2. Baskı). Ankara: Nobel Yayın Dağıtım.

Senemoğlu, N. (2009). Gelişim Öğrenme ve Öğretme. Ankara: Pegem Akademi Yayıncılık.

Shank, M. D., Walker, M., \& Hayes, T. (1995). Understanding Professional Service Expectations: Do We Know What Our Students Expect in a Quality Education? Journal of Professional Services Marketing, 13, 71-89. http://dx.doi.org/10.1300/J090v13n01 08

Sönmez, V. (1990). Sevgi Ĕ̆itimi (2th ed.). Ankara: Adım Yayıncılık Lmt. Şti.

Sosik, J. J., \& Godshalk, M. (2000). The Role of Gender in Mentoring: Implications for Diversified and Homogenous Mentoring Relationships. Journal of Vocational Behavior, 57, 102-122.

Stevenson, K., MacKeogh, K., \& Sander, P. (2006). Working with Student Expectations of Tutor Support in Distance Education: Testing an Expectations-Led Quality Assurance Model. Open Learning: The Journal of Open, Distance and e-Learning, 21, 139-152. http://dx.doi.org/10.1080/02680510600713169

Stevenson, K., Sander, P., \& Naylor, P. (1997). ELPO—A Model that Uses Student Feedback to Develop Effective Open Tutoring. Open Learning: The Journal of Open, Distance and e-Learning, 12, 54-59.

http://dx.doi.org/10.1080/0268051970120207

Stufflebeam, D. L. (2000). The CIPP Model for Evalutaion. In D. L. Stufflebeam, G. F. Madaus, \& T. Kellaghan (Eds.), Evalutaion Models: Viewpoints on Educational And Human Services Evaluation (2nd ed., pp. 280-317). Boston, MA: Kluwer Academic.

Sumsion, J. (1998). Stories from Discontinuing Student Teachers. Teachers and Teaching: Theory and Practice, 4, $245-258$.

Tanner, D., \& Tanner, L. (2007). Curriculum Development: Theory into Practice (4th ed.). Upper Saddle River, New Jersey Columbus, Ohio: Pearson Merrill Prentice Hall.

Trevethan, H. (2013). Associate Teachers in New Zealand: Great Expectations. Doctoral Dissertation, Dunedin: University of Otago. http://otago.ourarchive.ac.nz/bitstream/handle/10523/4677/TrevethanHelenW2014EdD.pdf?sequence=6

Türk Dil Kurumu (2013). Ruhbilim Terimleri Sözlüğü “Beklenti maddesi”. Türkiye. http://tdk.gov.tr/index.php?option=com_bilimsanat\&view=bilimsanat\&kategoriget=terim\&kelimeget=beklenti\&hngget= $\underline{\mathrm{md}}$

Varış, F. (1988). Eğitimde Program Geliştirme Teori ve Teknikler. Ankara: Ankara Üniversitesi Eğitim Fakültesi yayınları.

Vroom, V. (1964). Expectancy Theory. http://en.wikipedia.org/wiki/Expectancy_theory

White, C. (1999). Expectations and Emergent Beliefs of Self-Instructed Language Learners. System, 27, 443-457. http://dx.doi.org/10.1016/S0346-251X(99)00044-5

Yıldırım, A., \& Şimşek, H. (2011). Sosyal Bilimlerde Nitel Araştırma Yöntemleri (8th ed.). Ankara: Seçkin Yayınevi.

Yüksek Öğretim Kurulu (1998). Uygulamalı Dersler. Ankara: Yüksek Öğretim Kurulu. 
Zeichner, K. (2002). Beyond Tradional Structures of Student Teaching. Teacher Education Quarterly, 29, 59-64.

Zeichner, K. (2010). Rethinking the Connections between Campus Courses and Field Experiences in College- and UniversityBased Teacher Education. The Journal of Teacher Education, 61, 89-99. http://dx.doi.org/10.1177/0022487109347671

Zeithaml, V. A., Berry, L. L., \& Parasuraman, A. (1993). The Nature and Determinants of Customer Expectation of Service. Journal of the Academy of Marketing Science, 21, 1-12. http://dx.doi.org/10.1177/0092070393211001

\section{Appendix 1. The Information of Scale Related to the School Application Study Expectation of Prospective Teachers}

\begin{tabular}{|c|c|c|c|c|c|c|}
\hline Dimensions & $\begin{array}{l}\text { Items } \\
\text { No }\end{array}$ & Items & Communalities & $\begin{array}{l}\text { Rotated } \\
\text { load }\end{array}$ & $\begin{array}{l}\text { Standard } \\
\text { deviation }\end{array}$ & $\begin{array}{l}\text { Cronbach } \\
\text { Coefficient } \\
(\alpha)\end{array}$ \\
\hline \multirow{9}{*}{ Colleague } & i19 & $\begin{array}{l}\text { To reflect personality trait that is able to communicate } \\
\text { easily }\end{array}$ & .607 & .736 & .658 & .926 \\
\hline & i27 & To approach friendly in solving the problems at school & .629 & .687 & .698 & .927 \\
\hline & i25 & $\begin{array}{l}\text { To use a language that is capable for seeing missing and } \\
\text { positive aspects }\end{array}$ & .663 & 671 & .791 & .921 \\
\hline & $\mathrm{i} 21$ & To be sincere in human relations & .705 & .663 & .731 & .921 \\
\hline & $\mathrm{i} 29$ & To serve as a bridge in relations regarding applications & .626 & .617 & 1.018 & .942 \\
\hline & $\mathrm{i} 28$ & To guide vocational activities in a healthy way & .605 & .584 & .791 & .920 \\
\hline & i24 & To see the other person as a teacher by his/her behavior & 618 & .560 & .973 & .929 \\
\hline & $\mathrm{i} 22$ & $\begin{array}{l}\text { To use a style which is in a way of increasing a person's } \\
\text { self-esteem }\end{array}$ & 669 & .541 & .874 & .925 \\
\hline & i17 & To be genial during negotiations & .736 & .797 & .966 & .939 \\
\hline \multirow{8}{*}{ Guidance } & i5 & $\begin{array}{l}\text { To promote in preparing contemporary teaching-learning } \\
\text { environment }\end{array}$ & .733 & .692 & 1.069 & .884 \\
\hline & i9 & To give feedback on Positive or missing aspects & .653 & .651 & 1.036 & .886 \\
\hline & i4 & To help in the preparation of lesson plans or activities & .585 & .651 & .913 & .887 \\
\hline & i3 & To give information on education programs & 623 & 637 & .943 & .881 \\
\hline & i8 & To enrich supplementary resources & .708 & .594 & .765 & .885 \\
\hline & i15 & To make the evaluation together & .660 & .590 & 1.238 & .883 \\
\hline & i16 & $\begin{array}{l}\text { To set evaluation about his/her own teaching practice in a } \\
\text { reflective way (reflective thinking) }\end{array}$ & .514 & .533 & .964 & .899 \\
\hline & i12 & To guide in seeing the theory-practice interaction & .603 & .695 & 1.304 & .885 \\
\hline \multirow{4}{*}{ Leadership } & i11 & $\begin{array}{l}\text { To add specific days and weeks/official holidays to his/her } \\
\text { activities }\end{array}$ & .786 & 683 & 1.275 & .857 \\
\hline & i7 & To provide options for improving their teaching skills & .723 & 680 & 1.166 & .867 \\
\hline & i26 & To create a warm atmosphere with the language s/he uses & .752 & .651 & 1.238 & .920 \\
\hline & i2 & $\begin{array}{l}\text { To give information about the operation and rules of the } \\
\text { practice school }\end{array}$ & .717 & .486 & 1.000 & .919 \\
\hline
\end{tabular}

